$\stackrel{\odot}{\text { III }}$

\title{
CZEGO WARTO SIĘ UCZYĆ W ZAKRESIE ZARZĄDZANIA OD DALEKIEGO WSCHODU?
}

\begin{abstract}
Leszek Karczewski, Czego warto się uczyć w zakresie zarzq̨dzania od Dalekiego Wschodu? [What is worth to learn in management from the Far East?] edited by W. Banach, M.A. Michalski, J. Sójka, "Człowiek i Społeczeństwo” vol. XLVI: Między Chinami a Zachodem. Pytanie o źródła chińskiego sukcesu gospodarczego [Between China and the West. An inquiry into the sources of the Chinese economic miracle], Poznań 2018, pp. 159-174, Adam Mickiewicz University. Faculty of Social Sciences Press. ISSN 0239-3271.
\end{abstract}

The article emphasizes the need of learning from one's own history mistakes and the success of other countries such as Japan and China. The author presented the current situation of Poland in both skeptical and optimistic perspectives. The transformation of 1989 is indicated as the genesis of current challenges of the country. In the next part of the article there are suggested actions that could be taken after the transformation in the field of state and organization management in order to realize the idea of Poland as the "second Japan". The last part of the article is devoted to describing what can still be learned from the Far East countries in the field of economy and management.

Leszek Karczewski, Politechnika Opolska, Katedra Nauk Humanistycznych i Prawnych, Wydział Ekonomii i Zarządzania, ul. Nysy Łużyckiej 7, 45-036 Opole, e-mail: I.karczewski@po.opole.pl

\section{Wprowadzenie}

Brak wiedzy nie jest grzechem, jest czymś naturalnym, lecz czymś innym jest ignorancja wiedzy. Wiedzy na każdy niemal temat nie brakuje, jej zasób jest ogromny, nawet wiedza poszczególnych jednostek, które żyją 
dostatecznie długo, jest spora. Pokaźny jest zasób wiedzy każdego narodu, a jakże wielki całej ludzkości, lecz coś w nas samych i w strukturach społecznych przeciwstawia się wykorzystaniu go w rozwoju człowieka jako jednostki i jako gatunku w różnych wymiarach - materialnym, intelektualnym i duchowym.

Szczególny zasób wiedzy tkwi w starych narodach, takich jak naród japoński, chiński, koreański czy indyjski. Warto sięgnąć do niego, aby nie popełniać tych samych błędów, aby nie narażać siebie lub innych na zbędne cierpienie. Już Budda 500 lat p.n.e. twierdził, że życie jest cierpieniem, lecz nie zachęcał do cierpienia jako takiego, zachęcał raczej do cierpliwości i do uwolnienia się od zbędnego cierpienia wynikającego z niewiedzy, ignorancji, zachłanności, braku uważności i umiaru. Wiedza jako przeciwieństwo niewiedzy prowadzić ma do życia w świetle, w stanie względnie stałej i trwałej radości, równowagi, harmonii wewnętrznej i zewnętrznej. Oto cel życia - żyć samemu szczęśliwie i uszczęśliwiać innych, a przynajmniej innym nie szkodzić. Niezależnie od tego, jaki zawód wykonujemy, z wyjątkiem takich, które związane są z hazardem, nierządem, zabijaniem innych, cel ten jest, zdaniem Buddy, możliwy do realizacji już w trakcie ludzkiego życia.

Jak trafnie zauważył współczesny wpływowy przywódca duchowy Indii Sathya Sai Baba, „Miliony osób potrafi dziś czytać i pisać, miliony posiada stopnie naukowe i jest ekspertami oraz specjalistami z różnych dziedzin. Oznaczać to może jednak tylko to, że są one sprawnymi kolekcjonerami informacji lub encyklopediami ogólnej wiedzy” ${ }^{1}$. Twierdził także, że bez jedynki duchowości nasza wiedza i umiejętności są jak sumowane ze sobą zera - nie mają żadnej trwalszej wartości. Możemy zatem poszukać na Wschodzie tej jedynki teleologii, duchowości, sensu, celu. Możemy też przeszukać głębiej zasoby duchowości (etyki) w naszej własnej cywilizacji, zrozumieć ją bardziej i dowartościować, uzupełnić i wykorzystać, promować po to, aby po prostu nie pozostać w tyle za innymi krajami i aby w pełni przeżyć dobre życie, w harmonii ze światem.

Celem poniższych rozważań jest próba zbliżenia się do odpowiedzi na pytania: Czego warto było uczyć się od Dalekiego Wschodu w zakresie zarządzania państwem i organizacjami w naszej niedalekiej przeszłości, np. w okresie transformacji rozpoczętej w 1989 r. i w czasie po niej następującym? Czego nadal warto się uczyć?

\footnotetext{
${ }^{1}$ Sathya Sai Baba, Sathya Sai Speaks, Vol. 6, Ch. 25, Puttaparthi, India, b.r.w.
} 


\section{Patrząc za siebie i przed siebie: czego warto było uczyć się od Dalekiego Wschodu?}

Według Kennetha Bouldinga na rozwój ekonomiczny duży wpływ wywierają czynniki kulturowe, takie jak: wychowanie, model życia, zwyczaje związane z pracą, a w szczególności to, w co ludzie wierzą ${ }^{2}$. Rozwój wymaga ponadto: innowacji, naśladownictwa i akumulacji kapitału. Najbardziej istotna innowacja w każdym społeczeństwie, to - zdaniem tego ekonomisty - sama idea zmiany, a głównym czynnikiem historycznym wywołującym zmianę jest reforma w zakresie tego, w co ludzie wierzą ${ }^{3}$. To, co Boulding nazwał wiarą, można by rozszerzyć na inne istotne kwestie, niekoniecznie transcendentalne, takie jak wiara/niewiara w: wolny rynek, demokrację, wyższość/niższość Zachodu nad Wschodem, nadrzędność jednostki nad grupą lub przeciwnie itd. W dalszej części artykułu przedstawiono pewne aspekty naszej „,horyzontalnej wiary” i skutków tej „wiary” w wymiarze społecznym.

\section{Dlaczego patrzeć za siebie?}

Warto sięgać pamięcią wstecz, aby nie było jak w wierszu Jana Kochanowskiego: „Cieszy mię ten rym: »Polak mądry po szkodzie«;/ Lecz jeśli prawda i z tego nas zbodzie,/ Nową przypowieść Polak sobie kupi,/ Że i przed szkodą, i po szkodzie głupi”4 . Chodzi jednak o to, aby „nie płakać nad rozlanym mlekiem”, ale uczciwe odpowiedzieć na pytanie i postawić diagnozę: jak jest. Diagnoza powinna być zatem wolna od hurraoptymizmu, ale też wolna od użalania się nad sobą, dążenia do wyrównywania rachunku krzywd czy budowania kapitału politycznego. Audyt w wymiarze jednostkowym, organizacyjnym i społecznym jest jednym z warunków niepowtarzania tych samych błędów, „nadeptywania ciągle na te same grabie”. Warto więc uczyć się od siebie samych, z własnej i cudzej historii, zwłaszcza że, jak powiada stare przysłowie, „gdzie dwóch się bije, tam trzeci korzysta”.

${ }^{2}$ Zob. K. Boulding, Religijne podstawy postępu ekonomicznego, w: J. Grosfeld (wybór i przekład), Religia i ekonomia, PAX, Warszawa 1987, ss. 48-62.

${ }^{3}$ Zob. K. Boulding, Religijne perspektywy ekonomii, w: J. Grosfeld (wybór i przekład), op. cit., ss. 67-68.

${ }^{4}$ J. Kochanowski, Pieśni. Księgi wtóre, Pieśń 5, https://staropolska.pl/renesans/jan_ kochanowski/piesni/piesni_31.html, dostęp: 2.12.2018. 
W historii Polski wielokrotnie różne państwa korzystały na naszej słabości wewnętrznej, na prywacie, braku współdziałania, na „wojnach polsko-polskich”, na nieuzasadnionej „wierze” Polaków w wyższość zachodniej kultury.

\section{Wnastroju nieco sceptycznym:jak jest?}

Jak wskazują badania agencji Bloomberg/IIF, wśród światowych gospodarek wschodzących Turcja, Węgry i Polska to kraje o najwyższym udziale zadłużenia zagranicznego w relacji do PKB (ponad 50\%). Kraje te są najbardziej narażone na wahania nastrojów i odpływ kapitału. Geneza tej sytuacji to „objadanie się tanim pieniądzem”. Dla porównania, w Chinach i Indiach udział zadłużenia zagranicznego w relacji do PKB to nie więcej niż 15\%. Potencjalne podrożenie pieniądza może wpłynąć na to, że długi wzrosną i trzeba będzie sięgać głębiej do kieszeni podatnika. Dotknie to zwłaszcza bezbronnej wobec decydentów sfery budżetowej, zwłaszcza edukacji każdego szczebla, co spowodować może zmniejszanie wydatków na nią, które już dzisiaj nie są wystarczające. Inna jeszcze kwestia to niska rentowność polskich firm. Polskie firmy - poddostawcy - mają rentowność 3\%, a firmy, do których dostarczają półprodukty - $60 \%{ }^{5}$. Istnieje niebezpieczeństwo, że te ostatnie znajdą sobie podwykonawcę za $2 \%$ marży. Wskazuje się więc na konieczność rozwoju własnych technologii w poszczególnych niszach.

Geneza tej niezbyt komfortowej sytuacji leży zapewne także w polskiej transformacji, którą opisał i krytycznie ocenił prof. Witold Kieżun ${ }^{6}$. Według tego wybitnego teoretyka i praktyka zarządzania elementy liberalne nie były uzupełnione o socjalne ${ }^{7}$. Główna teza jego pracy brzmiała, że nastąpił proces peryferyzacji i neokolonizacji polskiej gospodarki ${ }^{8}$. Państwo polskie stało się ofiarą zorganizowanego rabunku; nastąpiła bolesna utrata majątku narodowego i przez dwie dekady nasza gospodarka nie mogła odzyskać sił . W świetle jego badań w trakcie transformacji upadło około pięciuset dużych

5 Zob. A. Koziński, G. Friedman, Wszystkie mocarstwa w końcu upadajq - wywiad w „Nowej Trybunie Opolskiej” z dnia 11.06.2018, s. 11 - dodatek „Polska za 100 lat”.

6 Zob. W. Kieżun, Patologia transformacji, wyd. 2 uzup., Wyd. Poltext, Warszawa 2013.

7 Ibidem, s. XIII.

${ }^{8}$ Ibidem, ss. III, XX, XXI. Mowa tu o strukturalnej patologii polskiej gospodarki kapitał zagraniczny kontroluje 20\% produkcji przemysłowej i 80\% aktywów sektora bankowego, podobnie handlu. Urzędy państwowe mają rachunki na kontach kontrolowanych przez banki zagraniczne.

${ }^{9}$ Ibidem, ss. III, IV. 
firm, zakładów wysokiej techniki1 ${ }^{10}$, spośród których znaczna część miała realne szanse na przetrwanie i rozwój pod warunkiem otrzymania pewnego wsparcia od państwa. Nastąpiły jednak wrogie przejęcia tych firm. W konsekwencji zwolnieni pracownicy zasilili szeregi bezrobotnych, ludzi niepotrzebnych nikomu, którzy przeszli na utrzymanie państwa. Wielu ludziom w tamtym czasie nie tylko nie dano, jak obiecywano, wędki, ale nawet odebrano rybę. Według cytowanego autora wystąpiły dokonane przez reformatorów projektowe błędy, u podstaw których leżały dwa czynniki. Jeden to kompleksy polskie i wynikająca z nich naiwność wobec „ludzi Zachodu” oraz bezkrytyczność wobec „podpowiedzi” Banku Światowego i Funduszu Walutowego ${ }^{11}$. Drugi czynnik to brak praktyki kierowniczej i odpowiednich kwalifikacji kadry przeprowadzającej transformację ${ }^{12}$. Skutek? Wprowadzono powielające się struktury władzy niezgodne z zasadami prakseologii - teorii sprawnego działania ${ }^{13}$. Nie skorzystano też z pozytywnych doświadczeń np. rządu Kanady, która stawiała zagranicznym inwestorom warunki korzystniejsze dla swojego kraju.

Skutek transformacji był również taki, że w niektórych, zwłaszcza mniejszych miastach Polski, np. w Nysie w województwie opolskim, stopa bezrobocia wynosiła 30\%!!! To tyle, ile w trakcie wielkiego kryzysu lat trzydziestych ubiegłego wieku w Ameryce. Obecny poziom bezrobocia w Polsce jest relatywnie niewielki, ale przez całe lata był bardzo wysoki. Efekt? Wyjazd około dwóch milionów polskich obywateli, głównie młodzieży. Wśród nich pewna część osób z wyższym wykształceniem opuściła granice kraju, zazwyczaj w sposób trwały. Odsetek powrotów jest niestety niewielki. Nie urodzi się więc w Polsce być może nawet dwa miliony nowych obywateli, zabraknie osób składających się na solidarnościowe emerytury. Częściowo złagodził to zjawisko napływ emigrantów z Ukrainy, ale nie do końca jest to pocieszeniem np. dla rodziców, których dzieci wyjechały na stałe za granicę ${ }^{14}$. Poza tym otwarcie granicy Niemiec w przyszły roku spowoduje, że część naszych wschodnich sąsiadów tam

${ }^{10}$ Ibidem, ss. 136, V, XV. Takim negatywnym przykładem były Zakłady Wytwórcze Urządzeń Telefonicznych w Warszawie, Węgrowie i Bydgoszczy. Dobra, technologicznie zaawansowana firma w sposób wrogi została przejęta przez Siemensa, produkcję przeniesiono do Niemiec i przejęto olbrzymie kontrakty handlowe rynków wschodnich.

${ }^{11}$ Ibidem, s. VII.

12 Ibidem, s. XIV.

${ }^{13}$ Ibidem, s. 297.

${ }^{14}$ Nie nastąpi też transfer zakumulowanej wiedzy od dziadków do wnuków, gdyż te ostatnie się nie urodzą lub będą mieszkać za granicą. 
właśnie wkrótce wyjedzie z Polski. Obecność dużej liczby emigrantów zza wschodniej granicy prawdopodobnie nie doprowadzi do konfliktów w Polsce na tle narodowościowym, choć prowadzone przez autora badania wskazują na to, że istnieją jednak takie obawy ${ }^{15}$. Zapewne warto byłoby monitorować ten problem i prowadzić na bieżąco badania w tym zakresie.

\section{W nastroju optymistycznym}

Jak twierdził Laurence J. Peter ${ }^{16}$, pesymizm może unicestwić ludzi szybciej niż bomby. Może więc lepiej podejść do sytuacji Polski w nastroju optymistycznym? Taki nastrój reprezentuje np. George Friedman. Zdaniem tego amerykańskiego politologa urodzonego w Budapeszcie w okresie najbliższej dekady sytuacja Polski ulegnie diametralnej zmianie na korzyść, zwłaszcza w kontekście realizacji koncepcji państw Trójmorza. Koncepcja ta wiąże się głównie z dystrybucją surowców energetycznych ze Stanów Zjednoczonych do Europy Środkowej i trójkąta współpracy USA - Rumunia - Polska ${ }^{17}$. Autor ten przewiduje także rozwój Turcji oraz osłabienie Chin i Niemiec (ze względu na zbyt duży eksport nad importem). Według tegoż autora Polska nie ma innego wyboru jak tylko sojusz z Ameryką, która w 2019 r. ma być największym producentem ropy z łupków.

Nie kwestionując oczywiście konieczności dywersyfikacji dostaw surowców ze względu na poziom bezpieczeństwa energetycznego kraju, być może jednak warto zadać pytanie o realne koszty takiej dywersyfikacji, przekładające się następnie na ceny innych towarów. Również sama koncepcja Trójmorza (Tree Sees Initiative) napotyka w praktyce wiele przeszkód związanych z rozbieżnościami interesów poszczególnych państw ${ }^{18}$. Jest także „klinem” między Unią Europejską a Polską.

${ }^{15}$ Zob. L. Karczewski, Bezpieczeństwo narodowe w opiniach studentów i absolwentów Politechniki Opolskiej i PWSZ w Raciborzu z lat 2011-2016, w: L. Karczewski, H. Kretek (red.), Społeczno-prawne wyzwania gospodarki biznesu i zarzqdzania, Oficyna Wydawnicza Politechniki Opolskiej, Opole 2016, s. 98. Na pytanie: „W jakim stopniu Pana/i zdaniem emigranci ze Wschodu stanowią potencjalne zagrożenie dla bezpieczeństwa państwa polskiego?” 40\% respondentów wybrało wskazania „w stopniu dużym” i „w bardzo dużym stopniu".

16 Zob. L.J. Peter, R. Hull, Zasada Petera, KiW, Warszawa 1977.

17 Zob. A. Koziński, G. Friedman, Wszystkie mocarstwa..., s. 02.

${ }_{18}$ Zob. Ł. Wojcieszak, Bezpieczeństwo energetyczne państw Trójmorza - wyzwania i perspektywy w: L. Karczewski, H. Kretek (red.), Biznes i zarzq̨dzanie w Polsce i na świecie, Oficyna Wydawnicza Politechniki Opolskiej, Opole 2018, s. 131. 


\section{Czego warto się było uczyć od Dalekiego Wschodu w zakresie ekonomii i zarządzania w okresie transformacji?}

\section{Poziom makro. Zbudować druga Japonię}

Hasło zbudowania drugiej Japonii rozbrzmiewało w Polsce w okresie początkowym transformacji. Poza hasłami nie podjęto jednak poważnych działań operacyjnych w tym kierunku, gdyż, jak się wydaje, nie było to zbieżne z obowiązującymi światowymi trendami, a moda była na koncepcje neoliberalne lub zbliżone do nich. Z przykładu Japonii skorzystały z dużym powodzeniem gospodarki Tajwanu, Singapuru, Korei Południowej, a później także Chin.

Gdyby jednak spróbowano w Polsce skorzystać przynajmniej z niektórych japońskich wzorców, co można było wtedy zaadaptować? Podstawą działań doskonalących powinna była być koncepcja myślenia i działanie w kategoriach „my”, a nie „ja”, czyli, przekładając na język praktyki: co możemy produkować, aby rozwinąć całe społeczeństwo również pod względem intelektualnym. Koncepcja „my” była jednak w Polsce niepopularna z różnych względów historycznych oraz panujących na indywidualizm metodologiczny oraz minimalistyczne państwo mód. W Japonii, przyjmując ograniczoną „wiarę” w tzw. „niewidzialną rękę rynku” i w dobrą wolę obcego biznesu oraz zagranicznych polityków, państwo zastosowało działania wspierające własną gospodarkę, np. leasing maszyn, ubezpieczenie działalności proeksportowej firm i czasową ochronę własnych producentów. Producenci mieli możliwość ubezpieczenia swojej działalności proeksportowej, zmniejszając w ten sposób ryzyko niepowodzeń. Eksport rozwijał się więc w niesamowitym tempie. Pomoc rodzimym przedsiębiorstwom zamierzającym eksportować swoje towary okazała, również z pozytywnym skutkiem dla całej gospodarki narodowej, Korea Południowa ${ }^{19}$.W Polsce zabrano się za to stosunkowo późno, by nie rzec - zbyt późno, w porównaniu z innymi krajami.

Gdyby pomyślano w tych kategoriach, być może udałoby się nie dopuścić do takiej skali bezrobocia i do takiego exodusu młodzieży - przyszłych

${ }^{19}$ Zob. F. Fukuyama, Zaufanie. Kapitał społeczny a droga do dobrobytu, Wydawnictwo Naukowe PWN, Warszawa-Wrocław 1997. 
podatników - do jakiego doszło. Nie trzeba było być jasnowidzem Klimuszką, aby przewidzieć skutek: z kraju wyjechało około dwóch milionów obywateli (co najmniej 5\% całej populacji). Podobnie, ale na większą jeszcze skalę, rzecz się miała na Litwie (13\%), w Bułgarii (25\%) i innych krajach Europy Środkowo-Wschodniej.

\section{Poziom organizacji}

Już Lao Tzu w Tao te Ching sugerował, że należy stawiać czoła sytuacjom trudnym, kiedy są łatwe do przezwyciężenia, oraz dokonywać wielkich czynów za pomocą małych działań. W innym miejscu swego dzieła pisał, że z rządzeniem krajem jest jak ze smażeniem małych rybek. Nie wolno ich zbyt często i szybko mieszać, żeby się nie rozpadły ${ }^{20}$. Można więc powiedzieć, że wielki myśliciel starożytnych Chin był jednym z prekursorów koncepcji powolnych, lecz systematycznych zmian w organizacjach.

Koncepcji tej nie zastosowano jednak w Polsce, choć warto było to uczynić zarówno na poziomie makro, jak i mezo. Kaizen to zmiany powolne, a nie operacja „bez znieczulenia” na żywym organizmie w duchu nauk „Chicago Boys” Miltona Friedmana. Zamiast tzw. innowacji warto było wykorzystać kaizen. Innowacje to nie jedyny sposób dokonywania konstruktywnych zmian. Innowacje to często radykalne i gwałtowne zmiany, o których z takim nie do końca uzasadnionym entuzjazmem się pisało i pisze nadal, choć nie spotykają się one już z takim zachwytem pracowników. Taką właśnie radykalną zmianę, która nie spotkała się z pełną aprobatą i wysoką moralną oceną ludzi, zastosowano w wielu polskich organizacjach różnego szczebla i różnego typu. Kapitalizm Żółtej Rzeki był procesem stopniowych reform, był więc zgodny z kaizen, a nie stanowił „terapii szokowej”21. Kaizen to rozwijanie się małymi krokami ${ }^{22}$.

Trzeba podkreślić, że keizen nie jest jakąś specjalnością Dalekiego Wschodu. Nie można w sposób zdecydowany stwierdzić, że nie pasuje on do naszej mentalności, do naszych kulturowych uwarunkowań, gdyż powstał gdzieś daleko. Wręcz przeciwnie - idea ta narodziła się na Zachodzie i ma ona swoją długą tradycję również w świecie zachodnim. Na zasadzie kaizen dokonał przemiany osobowości już Benjamin Franklin, stając się wzorem

\footnotetext{
${ }^{20}$ Zob. Lao Tzu, Tao Te Ching, Signet Classics, New York 2007.

${ }^{21}$ Zob. M. Leonard, Zrozumieć Chiny, Nadir/Media Lazar, Warszawa 2009, s. 115.

22 Zob. I. Masaaki, Kaizen - tajemnica sukcesu Japonii, Wyd. MT Biznes, Warszawa
} 1992. 
i autorytetem moralnym, a także autorytetem w zakresie sprawnego działania dla kilku pokoleń Amerykanów ${ }^{23}$.

W Ameryce zastosowano ideę kaizen, choć literalnie tak się ona nie nazywała, już w trakcie Wielkiego Kryzysu ${ }^{24}$. Również w czasie wojny, aby zlikwidować braki personelu, stworzony został przez rząd program Training Within Industry (TWI) wprowadzany w przedsiębiorstwach amerykańskich $^{25}$. Zgodnie z założeniami tego programu nie dokonywano radykalnych zmian, lecz postawiono na rozwój ustawiczny, bazujący na tym, co już jest. Promotorem tej idei był m.in. „ojciec jakości” w zarządzaniu William Edwards Deming. Zalecał on wykorzystywanie potencjału pracowników, wykorzystywanie w firmie skrzynek na ich pomysły, a także proponował dokonywanie dużych zmian, lecz poprzez małe kroki ${ }^{26}$. Istota metody polega na tym, że drobne zmiany pozwalają pracownikowi przełamać zniechęcenie i lęk przed zmianą, który jest ważną przeszkodą w dokonywaniu zmian, przeszkodą psychologiczną wynikającą z konstrukcji i działania mózgu²7. Działania te przyniosły wówczas oczekiwany efekt. Po wojnie pomysły Deminga nie były już tak powszechnie praktycznie stosowane w Ameryce, a o Demingu niemal zapomniano. Japończycy natomiast chętnie skorzystali z jego doświadczenia i zaprosili go na pięć długich lat, by wygłaszał w Kraju Wschodzącego Słońca liczne wykłady na temat jakości ${ }^{28}$. Po powrocie z Japonii, mimo uzyskanej za granicą sławy, Deming nie znalazł swojego miejsca jako konsultant w żadnej amerykańskiej firmie. Stało się to dopiero wtedy, gdy w połowie lat osiemdziesiątych przemysł samochodowy w Stanach Zjednoczonych zaczął przeżywać poważny kryzys i został postawiony przez firmy japońskie niemal pod ścianą. Wówczas to zaproszono 85-letniego Deminga jako konsultanta do współpracy z firmami w Detroit. Analizując życie Deminga, aż chciałoby się zacytować, że „nikt nie jest prorokiem we własnym domu”, i to nawet w Ameryce.

Po wojnie koncepcja małych kroków znalazła w Japonii chętnych naśladowców. Przegranie wojny odbija się niekorzystnie na morale pracowników - efektywność ich pracy była na stosunkowo niskim poziomie.

${ }^{23}$ Zob. B. Franklin, Żywot własny, PIW, Warszawa 1960.

24 Zob. R. Maurer, Kaizen, Wyd. Helion, Gliwice 2007, s. 17.

${ }^{25}$ Ibidem, s. 17.

${ }^{26}$ Ibidem, s. 18.

${ }^{27}$ Ibidem, s. 24. W Polsce podobne idee promował Karol Adamiecki. Jednym z jego postulatów sprawnego działania organizacji było to, aby wprowadzać zmiany stopniowo.

${ }^{28}$ Zob. W. Latzko, D. Saunders, Cztery dni z dr. Demingiem. Nowoczesna teoria zarzqdzania, WNT, Warszawa 1998. 
Na zaproszenie rządu japońskiego i krajowej izby gospodarczej Japonii Amerykanie zorganizowali kursy pod nazwą Management Training Program (MTP ${ }^{29}$. Istotą proponowanego przez nich programu treningowego było przekonanie zarządzających, że to właśnie pracownicy powinni być traktowani jako główny zasób i źródło zmian, a nie gwałtowna reorganizacja narzucona im z góry przez menedżerów. W Japonii amerykańska strategia małych kroków została nazwana kaizen i szybko została tam zaadaptowana, przekładając się na szybki wzrost wydajności produkcjii ${ }^{30}$. Po niemal czterdziestu latach zapomnienia strategia małych kroków odrodziła się, choć z trudem, w Stanach Zjednoczonych, i to głównie w branżach zaawansowanych technologii. Kaizen jest jednak nadal metodą najpowszechniej stosowaną na Dalekim Wschodzie. W Japonii 90\% propozycji pracowników wprowadzanych jest w życie, a w Ameryce tylko $38 \%{ }^{31}$.

Czego jeszcze można było uczyć się od Dalekiego Wschodu w zakresie zarządzania? Wymieńmy tu choćby takie wskazania, jak zastosowanie taśmy produkcyjnej, przy której można siedzieć, a nie stać, i która zmienia tempo wraz z przybywaniem doświadczenia pracowników, zgodnie z zasadami ergonomii ${ }^{32}$. Pracownicy naszych firm produkcyjnych czy nawet sklepów usługowych do dzisiaj zmuszani są przez szefów do stania względnie chodzenia po sklepie niezależnie od tego, czy klient tam jest czy nie, bez żadnego racjonalnego uzasadnienia. Trudno za takie uznać stwierdzenia szefów: „bo przecież pracownikom za to się płaci”.

Podkreślanie atrybutów władzy jest „specjalnością” zarządzających wielu krajów Zachodu, z wyjątkiem może krajów skandynawskich ${ }^{33}$. Japońscy szefowie nie mają natomiast zastrzeżonych miejsc na parkingach. Nie mają wykwintnie urządzonych gabinetów i oddzielnej windy dowożącej ich z parkingu wprost do prywatnego gabinetu ${ }^{34}$. W Japonii nie istniały też okresowe zwolnienia pracowników, tak często praktykowane na Zachodzie. Firmy zachodnie są nierzadko polem bitwy między zarządem a robotnikami. Istnieją też w nich dwie przeciwstawne, wrogie sobie kultury organizacyjne: jedna

${ }^{29}$ Ibidem, s. 20.

${ }^{30}$ Ibidem, s. 21.

${ }^{31}$ Ibidem, s. 132.

32 Zob. D. Waters, Zarzq̨dzanie w XXI wieku. Jak wyprzedzić Japończyków i Chińczyków, WNT, Warszawa 1995.

${ }^{33}$ Zob. G. Hofstede, G.J. Hofstede, M. Minkov, Kultury i organizacje, PWE, Warszawa 2011, s. 86.

${ }^{34}$ Zob. G. Ogger, Zera w garniturach, Wyd. Profesjonalnej Szkoły Biznesu, Kraków 1994. 
to kultura zarządu, a druga pracowników. Na Wschodzie - w Japonii, Korei Południowej - mówi się o miłości do firmy opartej na zrozumieniu i poczuciu przynależności. Takie podejście do organizacji budzi w przeciętnym, chorobliwie nieufnym, sarkastycznym i we wszystko wątpiącym do granic możliwości człowieku Zachodu podejrzliwość, uśmieszek lub grymas na twarzy.

Ważną umiejętnością, którą warto było przejąć od Wschodu, był sposób podejmowania decyzji. Decyzje w Japonii zapadają zazwyczaj od dołu do góry. Japończycy od dawna twierdzą, że łatwiej zbudować fabrykę niż zgraną załogę. Kraje Zachodu dbają jednak głównie o menedżerów. Menedżer to osoba niemal „niezatapialna”, oczywiście dopóki jest młody lub nie zawini w sposób szczególny, np. ewidentnie okaże się mobberem lub, co nawet gorsze, nie zapewni właściwych wyników finansowych, głównie krótkoterminowych. Właściciele firm starają się ich właściwie motywować, a nawet w sposób irracjonalny starają się im przypodobać („złote spadochrony" - firma upada, ale menedżerom wypłaca się wysokie odprawy), ale nie jest tak, niestety, z pozostałymi pracownikami, zwłaszcza szeregowymi, którzy traktowani bywają w praktyce jako zamienny trybik w maszynie („wiecznie żywa” teoria X Taylora). Duch grupizmu - wspólnie pracować, bawić się i modlić - przyczynił się natomiast do zbudowania potęg gospodarczych krajów Dalekiego Wschodu, które zaczęły przejmować pałeczkę pierwszeństwa w świecie i niewątpliwie przyszłość, i to nie tak odległa, należy do nich. Wydaje się, że zachodni kult egoizmu i indywidualizmu wyczerpał już swoją siłę mobilizowania ludzi do działania, gdyż nie wskazuje im pewnego szerszego celu i sensu życia, który obejmować musi coś więcej niż interes własny. Mamy przecież głębokie potrzeby afiliacyjne (teoria potrzeb A. Maslowa, teoria homo sociologicus R. Dahrendorfa): większość czasu ludzkość przebywała jednak we wspólnocie pierwotnej i podświadomie ludzie mogą za tym „stanem umysłu” - „my” - tęsknić.

Kolejny ważny aspekt funkcjonowania firm to umiejętność współdziałania między organizacjami różnego typu. Przykładem takiej owocnej współpracy są w Japonii keiretsu. Firmy w danej branży i poza nią potrafiły w Japonii współpracować, odnosząc wspólne sukcesy. Powstawaniu klastrów w Polsce przeszkadza natomiast brak umiejętności współdziałania. Przykładowo, jedyny poważny klaster, jaki powstał w województwie opolskim Śląski Klaster Drzewny - stosunkowo szybko przestał sprawnie działać35.

35 Zob. E. Karaś, Aktywność małych i średnich przedsiębiorstw na przykładzie klastrów gospodarczych w województwie opolskim, w: W. Musialik, R. Śmietański (red.), Rzemiosło. Problemy doby współczesnej i czasów minionych, Wyd. „Solpress”, Opole 2017, ss. 93-94. 
Chiny tak błyskawicznie się obecnie rozwijające zawdzięczały swój sukces również korzystaniu z doświadczeń Japonii, choć kraj ten ze względów historycznych, z okresu m.in. II wojny światowej, nie kojarzy się tam dobrze. Potrafiono jednak wiele dobrego przejąć od swoich byłych nieprzyjaciół. Chiny twórczo skorzystały więc zarówno z doświadczeń Japonii, Singapuru i Tajwanu, jak i Zachodu. Wykorzystano tam także własne doświadczenia wielu tysięcy lat, doświadczenia chińskiej merytokracji - rządów ludzi kompetentnych, które były możliwe dzięki zastosowaniu egzaminów dla urzędników różnych szczebli36 ${ }^{36}$ Dla losów każdego kraju nieobojętne jest nie tylko to, w jaki sposób dokonuje się wyborów władz, ale też to, jacy w konsekwencji ludzie, o jakich walorach intelektualnych, emocjonalnych i moralnych, będą podejmować ważne dla kraju decyzje. Rządy osób niekompetentnych, szukających rozgłosu i realizacji swojego partykularnego interesu, lobbujących na rzecz różnych organizacji biznesowych krajowych czy zagranicznych, oparte na populizmie, mogą prowadzić do masowych protestów, chaosu, rozgrabienia i osłabienia kraju przez inne państwa, przez niektóre nieuczciwe transnarodowe korporacje, zagraniczny i rodzimy mafijny kapitał.

\section{Czego nadal można się uczyć od Wschodu?}

Wszystkie opisane powyżej koncepcje, które umożliwiły krajom Dalekiego Wschodu rozwijanie się w tak zadziwiająco szybkim tempie, są nadal aktualne i warto z nich skorzystać. Nadal można i warto się od nich uczyć. Żeby się jednak uczyć, trzeba wykazywać dobrą wolę i nawiązywać kontakty handlowe i kulturowe na większą jeszcze niż dotąd skalę, tak jak czyniło to nieprzerwanie i czyni wiele krajów świata.

Z dzisiejszego punktu widzenia można stwierdzić, że na początku lat dziewięćdziesiątych warto było za wszelką cenę zachować i rozwinąć kontakty handlowe z rynkami wschodnimi, zwłaszcza z rynkiem chińskim, i na pewno można było znaleźć mechanizmy umożliwiające utrzymanie wymiany handlowej z tymi rynkami. Transformacja przebiegłaby wtedy zapewne w znacznie łagodniejszy sposób. Nasze kontakty, a więc uczenie się, zostało jednak wtedy na długie lata, głównie ze względów ideologicznych, przerwane lub poważnie utrudnione. Można się wzajemnie uczyć, gdy następuje jakaś dyfuzja pomysłów, a to jest możliwe tylko w sytuacji wymiany informacji, kontaktów handlowych i relacji bezpośrednich.

${ }^{36}$ D.A. Bell, The China Model: Political Meritocracy and the Limits of Democracy, Princeton University Press, Princeton 2015. 
Kolejna kwestia godna zastosowania to teoria „rozbitych okien”. Jest ona znana na Zachodzie, lecz chętniej stosowana na Dalekim Wschodzie. Jej istotą jest to, że niezastąpienie wybitej szyby nową skutkuje często tłuczeniem kolejnych szyb ${ }^{37}$. Tolerowanie przez państwo małych naruszeń prawa przez obywateli, przewaga praw jednostki nad jej obowiązkami względem społeczeństwa jest przyzwoleniem dla egoizmu z jednej strony i popełniania poważnych zbrodni z drugiej. Mechanizm ciężkich przestępstw polega na tym, że ludzie są skłonni łamać prawo w środowisku, w którym istnieje na to przyzwolenie i gdzie mniejsze wykroczenia nie są zauważane ani karane. Daleki Wschód, np. Singapur, jest dobrą egzemplifikacją zastosowania tej teorii w praktyce. Podobnie Hongkong, który był niegdyś siedliskiem korupcji, a od wielu już lat w rankingach Transparency International znajduje się na czołowych miejscach miast o najniższym wskaźniku korupcji. Doprowadzono do tego stanu, dokonując ekstradycji skorumpowanych ludzi biznesu, członków rządu i funkcjonariuszy Policji, a także wprowadzając obowiązkowe zajęcia z etyki i etyki biznesu na wszystkich szczeblach edukacji oraz w zakresie programów i szkoleń etycznych w organizacjach biznesowych ${ }^{38}$.

Wiele ma nadal do zaoferowania filozofia kształtująca umysłowość ludzi Dalekiego Wschodu. Od buddyzmu można się nauczyć cnoty oszczędności. Filozofia ta nakłania do oszczędzania około 30\% dochodu. Chińczycy są znacznie bardziej oszczędnym narodem niż ludzie w krajach Zachodu. Również większe uwewnętrznienie byłoby korzystne dla ludzi Zachodu. W wielu zachodnich organizacjach powoli staje się to pewną modą - zarządzanie stresem, nauczanie sztuki medytacji. Interesującym faktem jest to, że około 30\% większych i średnich japońskich firm wysyła swoich pracowników na przeszkolenia do ośrodków zen w celu nabycia takich cech, jak: cierpliwość, wytrwałość, silna wola, spokój wewnętrzny, samodyscyplina i uważnośćc 39 .

Nadal warto uczyć się pewnej mądrości narodowej tych krajów umiejętności współpracy, ducha harmonii (he), inteligencji emocjonalnej, powściągliwości w uczuciach - kontroli emocji; opanowania smutku, gdy coś nie wychodzi, i wolności od hurraoptymizmu, gdy się coś udaje.

${ }^{37}$ Zob. R. Maurer, op. cit., ss. 124-125.

${ }^{38}$ Zob. W. Gasparski, Wykłady z etyki biznesu, WSPiZ im. L. Koźmińskiego, Warszawa 2000.

${ }^{39}$ Zob. K. Konecki, W japońskiej fabryce, Wyd. Instytutu Socjologii Uniwersytetu Łódzkiego, Łódź 1992, ss. 64-65. 
Konfucjańskie wskazania, takie jak pokora i skromność, szacunek dla starszych i przełożonych, cierpliwość, pogoda ducha, a także umiejętność działania przez dłuższy czas bez oczekiwania nagród, to cechy ludzi Wschodu. Nie są one, niestety, silną stroną ludzi Zachodu. Bez tych cech charakteru nie mamy szans na przegonienie lub choćby zbliżenie się do osiągnięć Japończyków czy Chińczyków. Czy powinniśmy jednak starać się im dorównać? Na pewno tak, gdyż inaczej staniemy się rodzajem „skansenu”; przewaga technologiczna Wschodu spowoduje, że będziemy czuć się coraz gorzej na ich tle. Brak postępu technologicznego, sztucznie wstrzymywanego przez niektóre korporacje zainteresowane sprzedażą przestarzałych technologii, to paradoksalnie również droga do tego, że nasze środowisko będzie coraz bardziej skażone. W Chinach natomiast coraz bardziej kładzie się nacisk na ochronę środowiska. Stają się tam na przykład coraz bardziej popularne silniki elektryczne (sprawność 80\%) napędzające samochody osobowe, motory, wózki transportowe itp., podczas gdy na Zachodzie dominują nadal przestarzałe silniki spalinowe, które dawno już powinny być wycofane z użytku, gdyż są mało sprawne (sprawność maks. 50\%), trudne w naprawie, wymagają wielotygodniowego szkolenia serwisantów i powodują ogromne skażenie środowiska naturalnego. Samochodowe korporacje zachodnie, chcąc utrzymać się na chińskim rynku, wręcz zmuszane są do montażu w sprzedawanych tam samochodach czy motocyklach silników elektrycznych.

\section{Podsumowanie}

Zgodnie z chińską filozofią nikt nie powinien iść przeciw swojej naturze oraz imitować cudzego stylu życia, gdyż może to spowodować frustrację i niedolę ${ }^{40}$. Dotyczy to także całych narodów. Kopiowanie od Zachodu czy od Wschodu cudzych pomysłów na życie, stylów życia, a także „jedynie słusznych” koncepcji ekonomii i zarządzania nie jest właściwe. Ekonomia i zarządzanie są naukami społecznymi, więc nawet gdyby chciały, nie są naukami ścisłymi. Kultura wywiera na nie ogromny wpływ. Nie oznacza to, że sprawdzonych doświadczeń nie można brać pod uwagę. Na pewno warto z nich korzystać, ale w sposób racjonalny, krytyczny i niejednostronny. W ostatnich trzydziestu latach w Polsce z tych doświadczeń nie korzystano

40 Jest to pewien aspekt chińskiej taoistycznej koncepcji wu wei. Zob. K. Wang, Chinese Philosophy on Life, Foreign Languages Press, Beijing 2005, s. 32. 
w taki właśnie sposób. Zwracaliśmy się, w poczuciu własnej niższości, z dużą dozą naiwności, w sposób jednostronny jedynie ku Zachodowi, ignorując Daleki Wschód pomimo jego ogromnych osiągnięć.

Polska leży pomiędzy Wschodem a Zachodem. Jest to szansą i zagrożeniem. Zagrożeniem, gdyż wszelkie wojny przetaczały się przez Polskę, gdyż z różnych stron byliśmy instrumentalnie traktowani przez inne narody wykorzystujące nasze wewnętrzne słabości i brak spójności. Szansą natomiast, ponieważ możemy być pomostem między nimi. Rozumiemy, czujemy i Wschód, i Zachód. Zawsze chcieliśmy i chcemy nadal być bardziej podobni do Zachodu. Zachód nam imponuje, a wobec Wschodu czujemy wyższość, czasami nawet niechęć. Dla Zachodu jesteśmy jednak także tylko Wschodem. Historia naszych relacji z Zachodem też powinna nas czegoś uczyć. Chwila obecna należy jeszcze do cywilizacji euro-amerykańskiej, ale niedaleka już przyszłość w coraz większym stopniu będzie należeć do Wschodu, do Azji. Wystarczy tam pojechać, wystarczy prześledzić trendy rozwojowe, aby uświadomić sobie, że czas cywilizacji Zachodu nieuchronnie i nieubłagalnie dobiega niestety końca, co „zawdzięczamy” m.in. naszemu skrajnemu indywidualizmowi, którym w dodatku tak się szczycimy.

\section{Literatura}

Bell D.A., The China Model: Political Meritocracy and the Limits of Democracy, Princeton University Press, Princeton 2015.

Boulding K., Religijne podstawy postępu ekonomicznego, w: J. Grosfeld (wybór i przekład), Religia i ekonomia, PAX, Warszawa 1987.

Boulding K., Religijne perspektywy ekonomii, w: J. Grosfeld (wybór i przekład), Religia i ekonomia, PAX, Warszawa 1987.

Franklin B., Żywot własny, tłum. Z. Kierszys, J. Stawiński, PIW, Warszawa 1960.

Fukuyama F., Zaufanie. Kapitał społeczny a droga do dobrobytu, tłum. A. i L. Śliwa, Wydawnictwo Naukowe PWN, Warszawa-Wrocław 1997.

Gasparski W., Wykłady z etyki biznesu, WSPiZ im. L. Koźmińskiego, Warszawa 2000.

Hofstede G., Hofstede G.J., Minkov M., Kultury i organizacje, tłum. M. Durska, PWE, Warszawa 2011.

Karaś E., Aktywność małych i średnich przedsiębiorstw na przykładzie klastrów gospodarczych w województwie opolskim, w: W. Musialik, R. Śmietański (red.), Rzemiosło. Problemy doby współczesnej i czasów minionych, Wyd. „Solpress”, Opole 2017.

Karczewski L., Bezpieczeństwo narodowe w opiniach studentów i absolwentów Politechniki Opolskiej i PWSZ w Raciborzu z lat 2011-2016, w: L. Karczewski, H. Kretek (red.), Społeczno-prawne wyzwania gospodarki biznesu i zarzq̨dzania, Oficyna Wydawnicza Politechniki Opolskiej, Opole 2016.

Kieżun W., Patologia transformacji, wyd. 2 uzup., Wyd. Poltext, Warszawa 2012. 
Kochanowski J., Pieśni. Księgi wtóre, Pieśń 5, https://staropolska.pl/renesans/jan_kochanowski/piesni/piesni_31.html, dostęp: 2.12.2018.

Konecki K., W japońskiej fabryce, Wyd. Instytutu Socjologii Uniwersytetu Łódzkiego, Łódź 1992.

Koziński A., Friedman G., Wszystkie mocarstwa w końcu upadajq - wywiad w „Nowej Trybunie Opolskiej” z dnia 11.06.2018, dodatek „Polska za 100 lat”.

Lao Tzu, Tao Te Ching, Signet Classics, New York 2007.

Latzko W., Saunders D., Cztery dni z dr. Demingiem. Nowoczesna teoria zarzq̨dzania, tłum. A. Erlich, WNT, Warszawa 1998.

Leonard M., Zrozumieć Chiny, tłum. W. Falkowski, Nadir/Media Lazar, Warszawa 2009.

Masaaki I., Kaizen - tajemnica sukcesu Japonii, tłum. K. Pawłowski, Wyd. MT Biznes, Warszawa 1992.

Maurer R., Kaizen, tłum. A. Erlich, Wyd. Helion, Gliwice 2007.

Morita A.G., Morita A., Reingold E., Shimomura M., Made in Japan. Akio Morita i Sony, WNT, Warszawa 1996.

Ogger G., Zera w garniturach, tłum. J. Mitręga, E. Szuptarska, A. Zaręba, R. Bator, M. Cyganik, B. Nowak, K. Spisak, G. Zaręba, D. Kałuża, Wyd. Profesjonalnej Szkoły Biznesu, Kraków 1994.

Peter L., Hull R., Zasada Petera, tłum. J. Kydryński, KiW, Warszawa 1977.

Sathya Sai Baba, Sathya Sai Speaks, Vol. 6, Ch. 25, Puttaparthi, India, b.r.w.

Wang K., Chinese Philosophy on Life, Foreign Languages Press, Beijing 2005.

Waters D., Zarzq̨dzanie w XXI wieku. Jak wyprzedzić Japończyków i Chińczyków, tłum. A. Erlich, WNT, Warszawa 1995.

Wojcieszak Ł., Bezpieczeństwo energetyczne państw Trójmorza - wyzwania i perspektywy, w: L. Karczewski, H. Kretek (red.), Biznes i zarzq̨dzanie w Polsce i na świecie, Oficyna Wydawnicza Politechniki Opolskiej, Opole 2018. 